\section{THE EFFECT OF CERTAIN BATHS AND FORMS OF ELECTRICITY ON THE BLOOD, BLOOD PRESSURE, AND METABOLISM;}

WITH REMARKS ON THEIR THERAPEUTIC USES.

BY WILLIAM BAIN, M.D. DuRH., M.R.C.P. LoND.;

WILFRID EDGECOMBE, M.D. LOND.,

PHYSICIAN TO THE HARROGATE INFIRMARY AND

HERBERT FRANKLING, M.R.C.S. ENG., L.R.C.P. LOND., HONORARY MEDICAL OFFICER TO OUT-PATIENTS, HARROGATE INFIRMARY.

THE following investigation was undertaken to ascertain the effect of certain baths and electrical procedures in use at Harrogate on the blood, on the blood pressure, and on metabolism as indicated by variations in the urinary constituents. It was primarily intended to investigate these points with reference to the more recently introduced electrical " baths" but it was thought that the usefulness of the research might be enhanced by extending it to include some of the otrer baths which have been long in use with the object of determining whether the physiological results obtained would furnish a rational basis for their therapeutic application. The subjects of the experiments were the authors themselves and the observations extended over 40 days. Their health was normal throughout; the results must therefore be regarded as purely physiological.

Points examined. - These consisted of the determination of the total daily excretion of urea, uric acid, sulphates, phosphates, chlorides, and acidity, the estimation of the hæmoglobin and red corpuscles, the enumeration of the leucocytes, and the measurement of variations in the blood pressure.

Methods adopted.-For the determination of urea the hypobromite method was adopted, Gerard's instrument being chosen. Uric acid was estimated by the Gowland-Hopkins' process; sulphates by the barium chloride method; phosphates by titration with uranium acetate; chlorides by Allen's modification of Mohr's method for the first three weeks, and subsequently by Volkard's method; acidity by titration with deci-normal caustic soda, phenolpht halein being employed as indicator. As regards the blood, hæmoglobin was determined by Oliver's hæmoglobinometer and the volume of the red corpuscles was estimated by Oliver's capacity tube. The leucocytes were counted in the 'Thoma-Zeiss chamber, the diluting fluid being acetic acid 0.3 per cent. with metbyl violet, and the amount of dilution 1 in 25. Blood pressure was determined by means of Oliver's hæmodynamometer. The total urine of the 24 hours was collected daily for the estimation of its constituents. The blood was examined once a day, the time chosen being immediately after rising in the morning when the blood is at its most constant point, before being disturbed by bath, exercise, or breakfast. It was also occasionally examined immediately before and after the baths, as will be detailed presently.

Diets: Subject $A$ (neight 11 stones 1 pound 7 ounces).Breakfast: bacon, 2 ounces ; egg, 1 ; toast, 2 ounces ; coffee, 15 ounces. Lunch : meat, 2 ounces; bread, 2 ounces cheese, $\frac{1}{2}$ ounce; biscuits, 2 ounces; banana, 2 ounces water, 10 ounces. Tea : tea, 8 ounces; biscuits, 2 . Dinner : meat, 4 ounces ; bread, 2 ounces ; cheese, $\frac{1}{2}$ ounce ; biscuits, 2 ; apple, 1 ; water, 10 ounces. Coffee ; 4 ounces. Bedtime: water, 10 ounces.

Subject $B$ (neight 12 stones 12 pounds).-Breakfast: egg 1 ; toast, $1 \frac{1}{2}$ ounces; coffee, 10 ounces. Lunch: meat, 2 ounces; ham, 1 ounce ; toast, $1 \frac{1}{2}$ ounces ; cheese, 1 ounce celery; milk, 10 ounces. Tea : tea, 12 ounces ; milk biscuits, 4 . Dinner: meat, 3 ounces; toast, $1 \frac{1}{2}$ ounces; cheese, $\frac{1}{2}$ ounce ; apple, 1 ; water, 10 ounces. Bed-time, water, 10 ounces

Subject $C$ (weight 13 stones 3 pounds).-Breakfast bacon, 2 ounces; egg, 1 ; bread, 1'- ounces ; tea, 20 ounces. Lunch : meat, 2 ounces ; cheese, $\frac{1}{2}$ ounce ; bread, $1 \frac{1}{2}$ ounces water, 10 ounces. Tea : tea, 8 ounces; biscuits, 3 . Dinner meat, 6 ounces ; cheese, 1 ounce ; bread, 2 ounces ; apples, 2 ; water, 20 ounces.

Normal standards of the three subjects.-Before determining these and to arrive at a condition of approximate equilibrium the diet was taken for a week before testing. Fistimations were then made daily for four days (in the case of Subject $\mathrm{C}$. for five days) and the average taken, the result being shown in Table $\mathrm{I}$.

TABLE I.

\begin{tabular}{|c|c|c|c|}
\hline 一 & A. & B. & C. \\
\hline Quantity $\quad \ldots$ & 1287 c.c. & 1243 c.c. & 1167 c.c. \\
\hline $\begin{array}{lll}\text { Urea } & \ldots & \ldots\end{array}$ & $32 \cdot 33$ grammes. & 33.92 grammes. & 27.62 grammes. \\
\hline Sulphates ... & $2 \cdot 30$ & $2 \cdot 15$ & $2 \cdot 13$ \\
\hline Uric acid $\quad \ldots$ & 0.701 & 0.528 & 0.656 \\
\hline $\mathrm{P}_{2} \mathrm{O}_{5} \quad \ldots \quad \ldots$ & $2 \cdot 49$ & $2 \cdot 32$ & $2 \cdot 31$ \\
\hline $\left.\begin{array}{c}\text { Chlorides in } \\
\text { terms of } \mathrm{NaCl}\end{array}\right\}$ & $12 \cdot 81$ & $11 \cdot 93$ & $13 \cdot 29$ \\
\hline $\left.\begin{array}{cc}\text { Acidity } & \text { in } \\
\text { terms } & \text { of } \\
\text { oxalic acid... }\end{array}\right\}$ & $3 \cdot 53$ & $3 \cdot 41$ & $3 \cdot 56$ \\
\hline $\begin{array}{l}\text { Leucocytes ... } \\
\text { Hæmoglobin } \\
\text { Corpuscles ... }\end{array}$ & $\begin{array}{l}7085 \text { per c. mm. } \\
95.0 \text { per cent. } \\
95.8 \quad,\end{array}$ & $\begin{array}{l}12,090 \text { per c.mm. } \\
107 \cdot 8 \text { per cent. } \\
109 \cdot 2\end{array}$ & $\begin{array}{l}7766 \text { per c.mm. } \\
101.6 \text { percent. } \\
100.4\end{array}$ \\
\hline Value $\quad \ldots \quad \ldots$ & 0.99 & 0.986 & 1.01 \\
\hline
\end{tabular}

The D'Arsonvad High-Frequency Current.

The extent to which this form of electricity has been used as a therapeutic agent during the last few years rendered the investigation of its physiological action on metabolism a matter of considerable interest. In examining the literature of the subject we were unable to find any detailed statements as to its effects in this direction. The following facts appear to have been established. Apart from its effects on motor and sensory nerves the respiratory combustion is in. creased, there being an increased excretion of $\mathrm{CO}_{2}$ under the current amounting to 37 litres per hour; a more active oxygenation of the blood takes place, leading to a plus heat production of from 79 to 127 calories per hour, the body temperature remaining normal; the excretion of nitrogen and $\mathrm{P}_{2} \mathrm{O}_{5}$ in the urine is increased. Nutrition is modified and a definite loss in weight varying from one to 28 ounces takes places during the passage of the current. ${ }^{1}$ The statements of various observers regarding its $\epsilon$ ffect on blood pressure are contradictory, some finding a rise in arterial tension and others a fall.

For the present investigation the current was administered by the method of auto-condensation (from 350 to 450 milliampères) for 30 minutes on four successive days, followed by the effleure of maximum intensity obtainable without sparking, applied to the whole surface of the body in succession for 30 minutes on two consecutive days.

Effect on blood pressure.--The effect varied according to the mode of application. Auto-condensation produced a slight transient rise in arterial pressure of from five to ten millimetres of mercury, rapidly falling, however, to normal, the net effect appearing to be nil.

TABLE II.

Subject $A$.

Radial pressure (recumbent) 95

30 minutes' auto-condensation from 350 to 450 milliampères-

Immediately after $\ldots \quad \ldots$ Radial pressure (recumbent) 105

5 minutes after

Subject $C$.

Before current

Radial pressure (recumbent) 110

30 minutes' auto-condensation from 350 to 450 milliampères-

Immediately after $\quad \ldots \quad \ldots$ Radial pressure (recumbent) 118

5 minutes after

The effleuve applied continuously to the whole surface of the body produced a distinct fall in blood pressure amounting to 10 or 15 millimetres of mercury. When applied, however, to the abdomen the pressure rose somewhat, though not to its original level. The duration of the fall in pressure after the current ceased to flow was variable but in no case prolonged. Sparking (from 100 to 150 milliampères) combined with gentle massage caused rapid hyperæmia when

1 Nightingale: Journal of Balneology and Climatology, July, 1904. 
vigorously done and gave rise to a papulo-erythematous rash which disappeared after 36 hours. The effect of this form is to cause a more persistent fall of arterial pressure.

\section{TABLE III.}

Subject $A$.

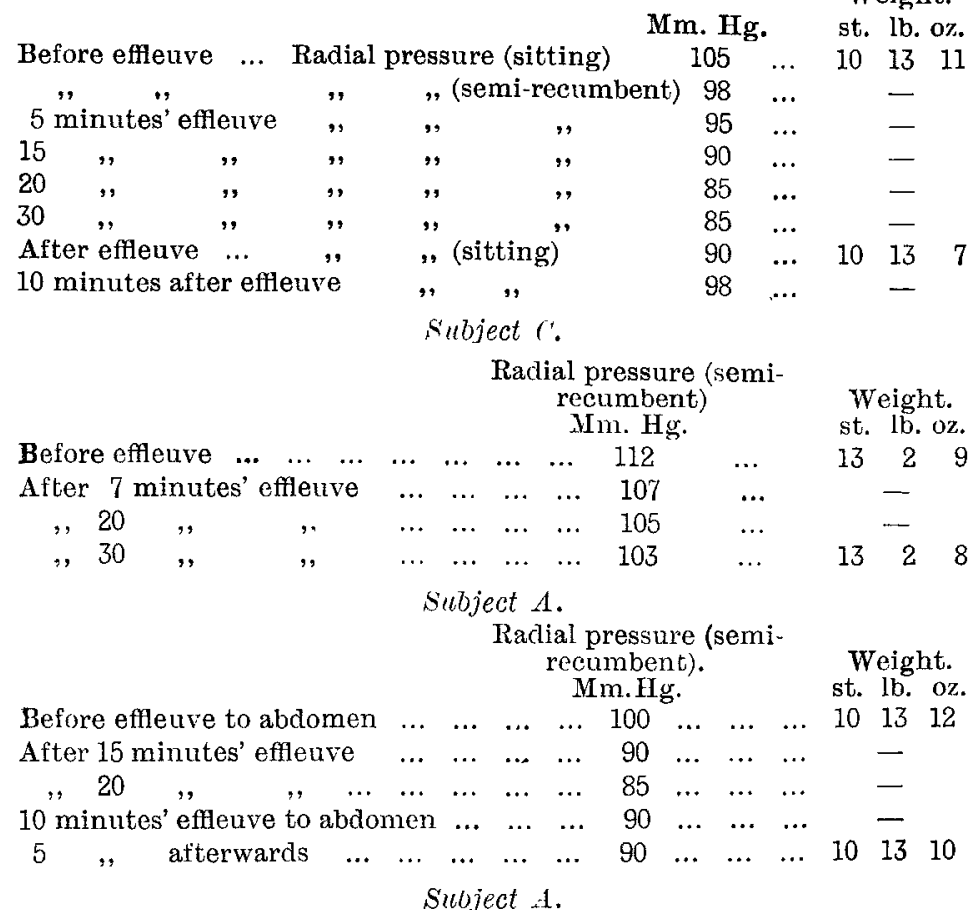

Before sparking ... ... Radial pressure (semi-recumbent) Mm. Hg After 15 minutes' auto-condensation and 15 minutes' sparking

to limbs and body $\quad \ldots \quad$ Radial pressure (semi-recumbent) $\quad \ldots \quad 85$

"It would thus appear that the divergent results on arterial pressure previously obtained may be due to the different forms of current employed, auto-condensation causing a temporary rise and the effleuve a decided fall, both results having been obtained on all occasions. From the above table it will be seen that a slight loss of weight, varying from one to four ounces, occurred in normal subjects, thus corroborating Nightingale's results.

Effect on the blood.-Observations on the blood immediately before and after the application of the current were not made. The morning observations, however, showed an increase in the amount of hæmoglobin during the days on which the current was taken over the average of the preceding days on which no current was applied. The corpuscles, on the other hand, were relatively diminished on the bath days, consequently there was in both the subjects of experiment an increase in the hæmoglobin "value " of the corpuscle ; in one case (Subject $C$ ) from 1.01 to 1.025 after six applications and in the other (Subject $A$ ) from 0.99 $1 \cdot 025$ after nine applications.

Effect on metabolism.-The effect on the urinary constituents is shown in the following table:-

\begin{tabular}{|c|c|c|c|c|c|c|}
\hline - & \multicolumn{2}{|c|}{$\begin{array}{c}\text { Average of } \\
\text { five preceding } \\
\text { days. }\end{array}$} & \multicolumn{2}{|c|}{$\begin{array}{l}\text { Average of four days' } \\
\text { auto-condensation, } \\
30 \text { minutes daily, } \\
\text { from } 350 \text { to } 400 \\
\text { milliamperes. }\end{array}$} & \multicolumn{2}{|c|}{$\begin{array}{l}\text { Average of two } \\
\text { days' effleuve, } \\
30 \text { minutes } \\
\text { each day. }\end{array}$} \\
\hline Quantity ... ... & 116 & & 119 & c.c. & 135 & e.c. \\
\hline Lrea $\ldots \ldots \ldots$ & $27 \cdot 62 \mathrm{~g}$ & mmes. & $33.39 \mathrm{~g}$ & mmes. & $32 \cdot 85 \mathrm{~g}$ & immes. \\
\hline Sulphates... ... & $2 \cdot 13$ & $\therefore$, & $2 \cdot 50$ & , & $2 \cdot 88$ &, \\
\hline Uric acid ... ... & 0.656 & , & 0.718 & , & 0.769 & , \\
\hline $\begin{array}{llll}\mathrm{P}_{2} \mathrm{O}_{5} & \ldots & \ldots & \ldots\end{array}$ & $2 \cdot 32$ & , & $2 \cdot 46$ & , & $2 \cdot 61$ & " \\
\hline Chlorides ... ... & $13 \cdot 29$ & , & $10 \cdot 75$ & , & $15 \cdot 37$ &. \\
\hline $\left.\begin{array}{r}\text { Acidity in terms } \\
\text { of oxalic acid }\end{array}\right\}$ & $3 \cdot 56$ & ", & $3 \cdot 25$ & , & $2 \cdot 84$ & , \\
\hline
\end{tabular}

It will be seen that the application of the current in these two forms in succession produced a marked increase in the excretion of urine, an increase in virea, uric acid, sulphates, and phosphates, and a marked diminution in acidity. In Subject $A$ the results were in the same direction though to a somewhat less extent. It would thus appear that the passage of the high-frequency current has a distinct effect upon the metabolic processes, a result which must be tentatively explained as the outcome of increased tissue change. It may be mentioned as a point of interest that both subjects were struck by the fact that the effleuve to the abdomen excited marked peristaltic action, leading to the free passage of flatus for some hours after exposure to the current and in one subject to repeated diarrhoea. This accords with the results of Crombie and Bokenham ${ }^{2}$ on the effect of the effleuve in promoting contraction of the stomach in cases of dilatation. Further, the rise in blood pressure which results when the effleuve is applied to the abdomen is in all probability due to stimulation of the splanchnic vessels.

\section{CONSTANT CURRENT AND SINUSOIDAL CURRENT IMMERSION} BATHS.

Sinusoidal current.- This bath was taken on three successive days. The water used was a mild alkaline sulphur water derived from the Beckwith Spring. It was given at a temperature of $98^{\circ} \mathrm{F}$., the duration of the bath being 20 minutes, during which time the alternating current (60 milliampères) was passing through the water.

Effeot on blood pressure.-No effect was observed other than that usually found as the result of an ordinary sulphur bath at a temperature of $98^{\circ}$ - viz., a fall of about 15 millimetres of mercury which returned, however, to the normal immediately after the bath, for example :-

\section{TABLE V.}

Subject $B$.

Before bath Madial pressure (recumbent)

Bath: Beckwith sulphur water $\left(98^{\circ}\right)$, sinusoidal current,

for 60 milliampères, 20 minutes :-

In bath 10 minutes $\quad \ldots \quad \ldots$ Radial pressure (recumbent) 85

$\begin{array}{lllllll}\text { ", , } 15 & \text { " } \quad \ldots & \ldots & \ldots & , & , & 80 \\ \text { Immediately after bath } & \ldots & ,, & , & 95\end{array}$

Effect on blood.-This was practically nil, no changes worthy of note being observed.

Effect on metabolism. - The sinusoidal current produced no distinctive change in the urinary constituents.

Constant current.-This bath was taken on four successive days, the same (Beckwith) water being used at a temperature of $98^{\circ} \mathrm{F}$.; the duration of the bath was 20 minutes with a current of 200 milliampères.

Effect on blood pressure.-No change in the blood pressure before and after the bath was observed. A warm sulphur bath at $98^{\circ}$ has usually the effect of reducing the blood pressure for a variable period after the bath and the effect of both sinusoidal and constant currents appears to be to abolish this fall and to maintain the pressure.

Effect on metabolism.--In contradistinction to the sinusoidal the constant current determined a slight increase in the excretion of urea and uric acid.

TABLE VI.-Subject $B$.

\begin{tabular}{|c|c|c|c|}
\hline- & $\begin{array}{l}\text { Average of three } \\
\text { free days. }\end{array}$ & $\begin{array}{l}\text { Average of three- } \\
\text { sinusoidal } \\
\text { baths. }\end{array}$ & $\begin{array}{l}\text { Average of four } \\
\text { constant cur- } \\
\text { rent baths. }\end{array}$ \\
\hline Quantity $\quad \ldots$ & 1047 c.c. & 1178 c.c. & 1102 c.c. \\
\hline $\begin{array}{lll}\text { Urea } & \ldots & \ldots\end{array}$ & 34.96 grammes. & $34 \cdot 78$ grammes. & 35.95 grammes. \\
\hline Sulphates ... & $2 \cdot 23$ & $2 \cdot 27$ & $2 \cdot 35$ \\
\hline Uric acid $\quad \ldots$ & 0.519 & 0.514 & 0.541 \\
\hline $\begin{array}{lll}\mathbf{P}_{2} \mathrm{O}_{5} & \ldots & \ldots\end{array}$ & $2 \cdot 29$ & $2 \cdot 19$ & $2 \cdot 33$ \\
\hline Chlorides $\quad .$. & $8 \cdot 47$ & $8 \cdot 32$ & $7 \cdot 8$ \\
\hline $\begin{array}{l}\text { Acidity in } \\
\text { terms of } \\
\text { oxalic acid }\end{array}$ & $2 \cdot 87$ & $2 \cdot 78$ & $2 \cdot 78$ \\
\hline $\begin{array}{l}\text { Leucocytes ... } \\
\text { Hæmoglobin.. }\end{array}$ & $\begin{array}{l}8346 \text { per c. mm. } \\
103.3 \text { per cent. }\end{array}$ & $\begin{array}{l}8200 \text { per c.mm. } \\
101.6 \text { per cent }\end{array}$ & $\begin{array}{l}8135 \text { per c.mm. } \\
106 \cdot 0 \text { per cent. }\end{array}$ \\
\hline $\begin{array}{c}\text { Red corpus } \\
\text { cles } \ldots \\
\text { "Value" }\end{array}$ & $\begin{array}{l}100.6 \\
1.027\end{array}$ & $\begin{array}{c}102.3 \quad, " \\
0.993\end{array}$ & $\begin{array}{rr}106 \cdot 0 & \\
1 \cdot 00\end{array}$ \\
\hline
\end{tabular}

Light AND OZONE BATH.

This bath is essentially an electric-light bath with the addition of the high-irequency current and the inhalation of an ozonised atmosphere. It consists of a large cabinet in which the patient lies on a glass shelf, exposed to the rays 
from a series of incandescent electric lamps suspended about 18 inches above the body, the eyes being protected from the glare by the interposition of a green shade. The temperature of the interior of the cabinet is usually about $100^{\circ} \mathrm{F}$., that of the surface of the body exposed to the heat being about ten degrees higher. During the bath a continuous manufacture of ozone is proceeding by means of a high-frequency current streaming off a circular brush electrode placed in a corner of the cabinet. The duration of the bath is usually 25 minutes, during the last ten of which a high-frequency current is passed through the body from a glass vacuum electrode held in the band. After the bath a sponge down is given preparatory to cooling off.

A good deal of work has been done on the physiological effect of electric light baths, notably by Kellogg ${ }^{3}$ and M. Cleaves, ${ }^{4}$ but, as in the bath under consideration, the two additional factors of the high-frequency current and the inhalation of ozone are introduced the results are not strictly comparable. Kellogg states that in the electriclight bath, sweating sets in earlier and is more profuse than in any other form of hot bath ; that the elimination of $\mathrm{CO}_{2}$ is greater; that there is a rise in body temperature during the bath; that there is an increase in the blood countespecially of the red cells-of from 10 to 20 per cent., which appears within half an hour and persists for some time and that in cases of marked anæmia the increase is usually permanent if daily application be made. Cleaves states that in some cases the hæmoglobin and corpuscles are increased but not in others. The bath was taken by two observers ; by one four days in succession, by the other three days.

Effect on blood pressure.-The blood pressure always showed a great fall-greater than is usually obtained by exposure to a similar degree of heat in any other form of hot bath. The fall, however, is of brief duration, disappearing soon after the bath, e.g. :-

\section{TABLE VII.}

S'ubject A.

Mm. Body temperature.

$\begin{array}{llllllllll}\text { Before bath } & \ldots & \ldots & \ldots & \text { Radial pressure (sitting) } & \ldots & 97 & \ldots & 98^{\circ} \mathrm{F}\end{array}$

Bath: temperature of cabinet, $100^{\circ} \ddot{\mathrm{F}}$; ; that of surface

of body exposed to light, $110^{\circ} \mathrm{F}$.-

In bath 5 minutes $\quad \ldots \quad$ Radial pressure (recumbent) $70 \ldots-$

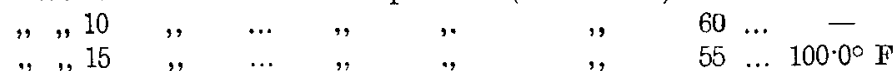

High frequency "urrent passed through body-

In bath 20 minutes ... Radial pressure (recumbent) $50 \quad \ldots \quad 100 \cdot 2^{\circ} \mathrm{F}$. 5 minutes after bath .. " $\quad, \quad, \quad 75 \quad \ldots .99 .80 \mathrm{~F}$.

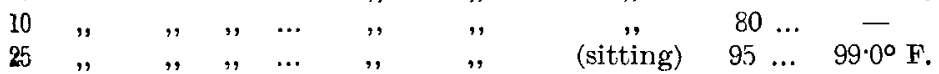

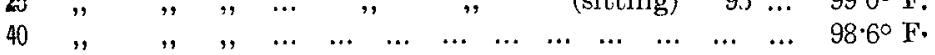

Effect on the blood.-The immediate effect on the blood taken before and after the bath was to cause an increase in the number of erythrocytes which attained its maximum about balf an hour after the bath.

TABLe VIII.

Subject A. Red corpuscles.

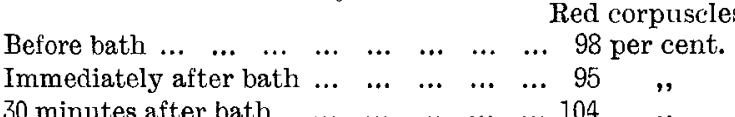

$\begin{array}{lllllllll}30 \text { minutes after bath } & \ldots & \ldots & \ldots & \ldots & \ldots & \ldots & & \\ 304 & ,\end{array}$

The morning examination of the blood showed that the series of baths caused a slight decrease in the amount of hæmoglobin and a marked decrease in the number of the corpuscles, with a consequent striking rise in the value of the corpuscle: in Subject A, from 0.99 to 1.045 ; and in Subject $B$, from 0.986 to 1.07 .

\section{TABLE IX.}

\section{subject $B$.} Arerage of four free days.

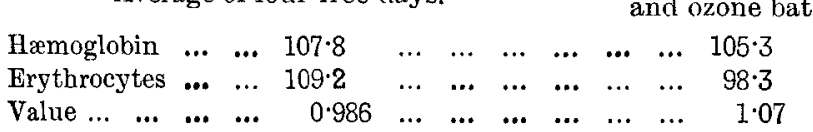

3 Cohen's System of Phvsiologic Therapeutics, vol. ix. 4 New York Medical Journal, 1899 .
Subject $A$

Average of free days

Average of all immediately pre-

ceding light and

$$
\text { ozone. }
$$

Average of three light and ozone baths.

$\begin{array}{llllllllllll}\text { II:moglobin } \ldots & . . & 94 \cdot 3 & \ldots & \ldots & 97 \cdot 0 & \ldots & \ldots & \ldots & \ldots & \ldots & 95 \cdot 2\end{array}$

$\begin{array}{lllllllllll}\text { Erythrocytes ... } & 94 \cdot 1 & \ldots & \ldots & 98 \cdot 0 & \ldots & \ldots & \ldots & \ldots & \ldots & \\ & \ldots & \ldots & \ldots & & \ldots & \end{array}$

$\begin{array}{lllllllllllll}\text { Value } & \ldots & \ldots & 1.00 & \ldots & \ldots & 0.99 & \ldots & \ldots & \ldots & \ldots & \ldots & 1.045\end{array}$

This conspicuous result raises the question, to which of the factors concerned is it to be attributed? It will be shown that the Dowsing radiant heat, which is essentially an incandescent electric-light bath, causes a fall in the value of the corpuscle-hence the rise obtained must be attributed to some other factor; and as the highfrequency current alone causes a slight but not marked rise the ozone remain's the probable cause. To determine this point exposure to the ozonised atmosphere within the cabinet for 25 minutes daily was undertaken on three successive days without the electric light and the high frequency current, and the blood was examined each morning and for three days previously. The result showed a rise in value from 0.986 to 1.043 , thus clearly proving ozone to be the factor concerned. The blood examined before and after inhalation of the ozone showed an immediate rise in value, in one case of 7 per cent. after 35 minutes in the cabinet, in another of 4 per cent. after 25 minutes.

\section{TABLE X.}

Subject $C$.

Value of corpuscle.

Average of three morning observations prior to ozone... 0.986 Average of three days' inhalation of ozone atmosphere

30 minutes each day

$$
\text { Subject } C \text {. }
$$

Red corpuscles, Hæmoglobin, Value of per cent. per cent. corpuscle.

Before exposure to ozone $\ldots \begin{array}{cccccccc} & 100 & \ldots & \ldots & 98 & \ldots & \ldots & 0.98\end{array}$

Immediately after 35

$\begin{array}{lllllllll}\text { minutes' exposure } \ldots & \ldots & 100 & \ldots & \ldots & 105 & \ldots & \ldots & 1.05\end{array}$

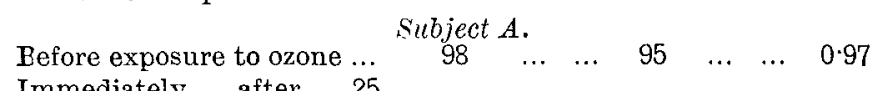

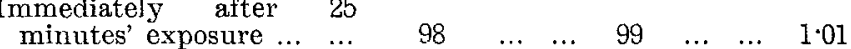

The suggestiveness of this result in the treatment of anæmia is sufficiently obvious to need no comment.

Effect on metabolism. - A reference to Table VII. will show that the body temperature is raised about $2^{\circ} \mathbf{F}$. during the bath. The effect of these baths on the urinary output appears to be slight. They produced in both subjects a diminution in the quantity of urine passed, a slight fall in the excretion of urea due probably to loss in the perspiration and a slight rise in the excretion of uric acid and phosphates, the sulphates being unchanged.

\section{SupERHEATEd AIR BATHS-DowSING-GREvILLE.}

The Dowsing and Greville systems of applying very high temperatures to the body either locally or generally are too well known to require detailed description, the Dowsing being a luminous heat supplied by ordinary incandescent lamps and the Greville a non-luminous heat engendered by the passage of an electric current through a large number of fine wires. The object of this investigation was to determine the effect of these baths on metabolism and the advantages, if any, possessed by one system over the other.

Donsing radiant heat bath.-This bath was taken by two observers, A. and C., in both cases on four successive days and at a temperature of from $280^{\circ}$ to $300^{\circ} \mathrm{F}$. applied to the whole body for 30 minutes.

Effect on the blood pressure.-Like all hot baths the Dowsing produces a marked fall in arterial blood pressure but, as will be seen on comparison with the results obtained in the Greville bath, the fall is greater at a lower temperature when the factor of light is introduced.

\section{TABLE XI.} Subject $C$.

Mm. Red cor- TemIIg. puscles. perature. Before bath... Radial pressure (sitting) $\quad \ldots \quad 115 \quad \ldots \quad 98 \% \quad \ldots \quad 972^{\circ} \mathrm{F}$ Bath $\left(280^{\circ} \mathrm{F}\right.$.) to whole body for 30 minutes. In bath 20 minutes. Radial pressure (re

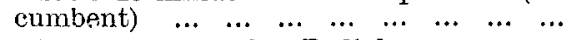
5 minutes after wath. Radial pressure (re$\begin{array}{llllllllll}\text { cumbent) } & \ldots & \ldots & \ldots & \ldots & \ldots & \ldots & \ldots & \ldots\end{array}$

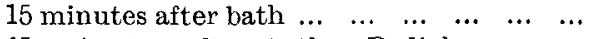
45 minutes after bath. Radial pressure 45 minutes after bath. Radial pressure $107 \ldots 0 \%$

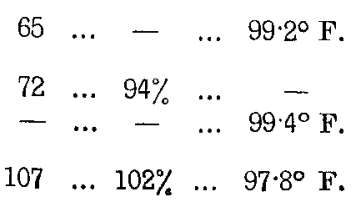


Fffect on the blood.-As will be seen in the above table the immediate effect on the blood is to cause a primary diminution in the number of corpuscles with a subsequent increase after the bath. The remote effect on blood examined on successive mornings is a marked reduction in the value of the corpuscle, in one case from an average of 1.00 to 0.973 (Subject $A$ ), in another from 1.002 to 0.957 (Subject C), as the result of 4 baths.

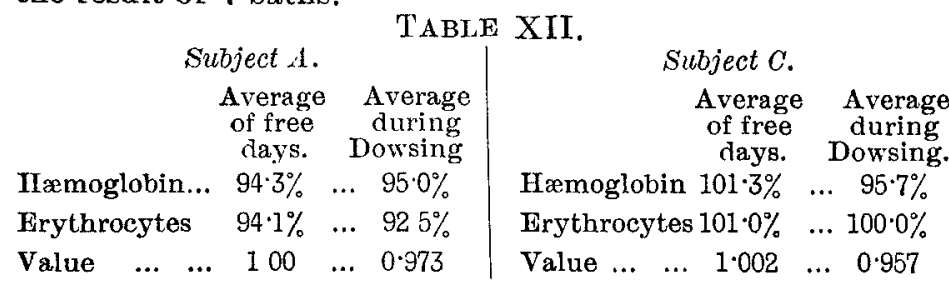

Effect on urinary constituents - A marked reduction in quantity of urine and a slight reduction in urea and acidity were observed, and a marked increase in uric acid output and in phosphates.

TABLE XIII.-Subject $A$.

\begin{tabular}{|c|c|c|c|c|c|c|}
\hline - & & & \multicolumn{2}{|c|}{ Average free days. } & \multicolumn{2}{|c|}{ Average Dowsing baths. } \\
\hline Quantity & $\ldots$ & & \multirow{2}{*}{\multicolumn{2}{|c|}{$\begin{array}{c}1251 \text { c.c. } \\
\text { 32.01 grammes. }\end{array}$}} & \multirow{2}{*}{\multicolumn{2}{|c|}{$\begin{array}{c}848 \text { c.c. } \\
30.41 \text { grammes. }\end{array}$}} \\
\hline Urea $\ldots$ & $\ldots$ & & & & & \\
\hline Sulphates & $\ldots$ & $\ldots$ & $2 \cdot 21$ & ", & $2 \cdot 19$ & ", \\
\hline Uric acid & $\ldots$ & $\ldots$ & 0.687 & ", & 0.776 & , \\
\hline $\mathbf{P}_{2} \mathrm{O}_{5} \quad \ldots$ & $\ldots$ & ... & 241 & , & $2 \cdot 86$ & $"$, \\
\hline Chlorides & $\ldots$ & $\ldots$ & $9 \cdot 77$ & , & $8 \cdot 44$ & , \\
\hline Acidity & $\ldots$ & $\ldots$ & $3 \cdot 22$ &, & $2 \cdot 54$ & $"$, \\
\hline
\end{tabular}

Greville bath. -This bath was taken by Subject C. on four successive days at a temperature of $300^{\circ} \mathrm{F}$. for 30 minutes. This temperature was more comfortably borne than a temperature of $280^{\circ}$ in the Dowsing bath, the scorching sensation experienced in the latter being notably absent. Sweating in this Subject (C) began sooner and was more profuse in the non-luminous heat than in the luminous lieat.

The effect on blood pressure is shown in the following table :-

\section{TABLE XIV. \\ Subject $C$.}

Mm. $\mathbf{H}_{\mathrm{g}}$. Body tem

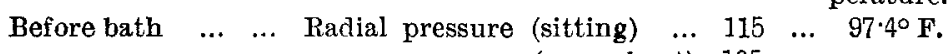

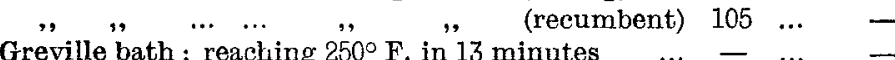

" " " $\quad 302^{\circ}$ F. in $27 \quad " \quad \ldots \quad \ldots \quad \ldots 9.8^{\circ} \mathrm{F}$.

In bath 32 minutes... Radial pressure (recumbent) 80 ...

15 minutes after bath $\quad, \quad \quad, \quad$ (sitting) $\ldots .90 \quad \ldots \quad 98 \cdot 6^{\circ} \mathrm{F}$.

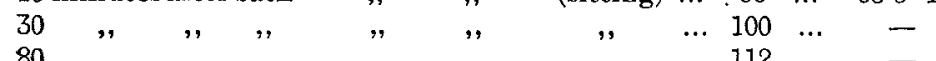

It will be seen that the reduction in blood pressure at a temperature of $300^{\circ} \mathrm{F}$. in the Greville bath is not so 1. reat as that caused by a temperature of $280^{\circ}$ in the Dowsing.

Effect on the blood.-A similar immediate diminution in the volume of the corpuscles took place during the bath with a subsequent rise about half an hour afterwards. The remote effect on the value of the corpuscle, however, differed from that obtained in the Dowsing bath, for a notable increase in hæmoglobin value was observed as the result of the four baths, the average value rising from 0.99 on the days prior to the bath to 1.02 on the bath days.

Effect on metabolism.-The following table gives the results obtained.

\begin{tabular}{|c|c|c|c|c|c|c|c|c|c|}
\hline & - & & & & & \multicolumn{2}{|c|}{$\begin{array}{c}\text { Average of free } \\
\text { days (before } \\
\text { bath). }\end{array}$} & \multicolumn{2}{|c|}{$\begin{array}{l}\text { Average, } \\
\text { Greville baths. }\end{array}$} \\
\hline Quantity & $\ldots$ & $\ldots$ & $\ldots$ & $\ldots$ & $\ldots$ & \multirow{2}{*}{\multicolumn{2}{|c|}{$\begin{array}{c}1190 \text { c.c. } \\
2925 \text { grammes. }\end{array}$}} & \multicolumn{2}{|c|}{1320 c.c. } \\
\hline Urea $\ldots$ & $\ldots$ & $\ldots$ & $\ldots$ & $\ldots$ & $\ldots$ & & & $29 \cdot 62$ & mmes. \\
\hline Sulphates & $\ldots$ & $\ldots$ & $\ldots$ & $\ldots$ & $\ldots$ & $2 \cdot 06$ & , & $2 \cdot 96$ & \\
\hline Uric acid & $\ldots$ & $\ldots$ & $\ldots$ & $\ldots$ & $\ldots$ & 0.654 & , & $0 \cdot 729$ & ," \\
\hline $\mathbf{P}_{2} \mathrm{O}_{5} \quad \ldots$ & $\ldots$ & $\ldots$ & $\ldots$ & $\ldots$ & $\ldots$ & $2 \cdot 17$ & , & $2 \cdot 45$ &,, \\
\hline Chlorides & $\ldots$ & $\ldots$ & $\ldots$ & $\ldots$ & $\ldots$ & $11 \cdot 13$ &, & $11 \cdot 65$ & , \\
\hline Acidity & $\ldots$ & $\ldots$ & $\cdots$ & $\ldots$ & $\cdots$ & 3.57 & " & $3 \cdot 14$ & ", \\
\hline
\end{tabular}

Contrasting these results with the Dowsing bath it will be seen that the quantity of urine is markedly increased. Now an increase of urine is usually accompanied by an increased excretion of urea, which, however, as the result of the baths, is not apparent in the table. There was, therefore, probably a relative diminution in the quantity of urea excreted by this channel. The uric acid was markedly increased, as occurred with the Dowsing bath, and an increase was observed in the sulphates and phosphates. It will therefore be seen that the great circulatory changes induced by both forms of baths have a marked effect in modifying the metabolic processes.

Comparing the results obtained from the two baths respectively it would appear that the effects common to both are an initial reduction of the volume of the corpuscles with a subsequent increase and a marked plus excretion of uric acid. On the other hand, the most important points of dissimilarity lie in the reduction of hæmoglobin value of the blood by the Dowsing bath and its increase by the Greville bath, and in the greater fall in blood pressure induced by the former than by the latter at corresponding temperatures. The explanation of these points of difference is not obvious. The only factor present in the Dowsing system, beyond those at work in the Greville system, is the presence of the light rays ; these, however, do not impinge directly upon the skin -a layer of lint intervening through which they must pass before reaching the surface.

It has been shown by one of $\mathrm{us}^{5}$ in experiments performed on the dog that luminous heat causes a greater reaction at a lower temperature and raises the body temperature both local and general, to a greater degree than the non-luminous heat. The hind limb of a dog was exposed to a temperature of $250^{\circ}$ in the Dowsing box for 45 minutes, at the end of which time the temperature of the venous blood returning from the limb had risen from $95 \cdot 8^{\circ}$ to $111^{\circ}$, and the general temperature of the body from $95.8^{\circ}$ to $99.3^{\circ}$. A similar experiment performed with the non-iuminous heat by the Greville system at a temperature of $300^{\circ}$ for 45 minutes (i.e., $50^{\circ}$ higher than the Dowsing bath) caused a rise of only $6 \cdot 6^{\circ}$ in the venous blood returning from the limb, and a rise of $1.8^{\circ}$ in the general body temperature.

\section{BERTHE AND VICHY BATH.}

This bath was taken by Subject $A$ on four successive days. It was investigated, since it is a bath in frequent use in this country and on the continent for chronic gout and other nutritional disorders. The bath consists of a preliminary exposure to steam heat at a temperature of $120^{\circ} \mathrm{F}$. for 15 minutes in the Berthe box - a closed cabinet in which the patient sits with his head protruding through an aperture in the top. This proceeding is then followed by massage administered for 20 minutes in the recumbent posture under a spray douche of from $98^{\circ}$ to $100^{\circ}$ projected upon the patient from a bracket suspended above the table and pierced by innumerable pin-holes. A needle douche begun at $98^{\circ}$ and gradually reduced to cool or cold completes the bath, after which the patient rests for half an hour or more till perfectly cool.

Effeot on blood pressure.-The following table will illustrate the changes which take place in blood pressure :-

\section{TABLE XVI.}

Subject $A$.

Before bath

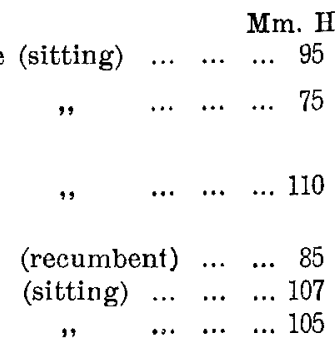

After 15 minutes

box at $120^{\circ} \mathrm{F}$.

Radial pressure (sittin

Mm. Hg

After 20 minutes' massage

and one minute in needle

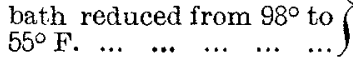

5 minutes after ... ... ...

15

30

It will be seen that the net effect is a rise in blood pressure, which may help to explain the notably invigoraling properties of this bath.

Effect on the blood. - The remote effect on the blood was to cause a slight rise in hæmoglobin value from $1 \cdot 01$, average on the three days prior to the baths, to 1.02 , average on the four days on which the bath was taken.

Effect on metabolism. - The effect on metabolism was not marked, as might have been expected, a slight rise in the urea, sulphates, and uric acid being noted. 
TABLE XVII.-Subjeot $A$.

\begin{tabular}{|c|c|c|c|c|c|c|c|c|c|}
\hline & - & & & & & \multicolumn{2}{|c|}{$\begin{array}{l}\text { Average three } \\
\text { free days. }\end{array}$} & \multicolumn{2}{|c|}{$\begin{array}{l}\text { Average four } \\
\text { days (Berthe } \\
\text { and Vichy). }\end{array}$} \\
\hline Quantity & $\cdots$ & $\ldots$ & $\ldots$ & $\ldots$ & & \multirow{2}{*}{\multicolumn{2}{|c|}{$\begin{array}{c}1141 \text { c.c. } \\
32 \cdot 18 \text { grammes. }\end{array}$}} & \multicolumn{2}{|c|}{1087 e.c. } \\
\hline Urea $\ldots$ & $\ldots$ & $\ldots$ & $\ldots$ & $\ldots$ & $\ldots$ & & & $33 \cdot 10 \mathrm{~g}$ & mmes. \\
\hline Sulphates & $\ldots$ & $\ldots$ & $\ldots$ & $\ldots$ & $\ldots$ & $2 \cdot 06$ & , & $2 \cdot 19$ & \\
\hline Uric acid & $\ldots$ & $\ldots$ & $\ldots$ & $\ldots$ & $\ldots$ & 0.686 &,, & 0.695 & \\
\hline $\mathrm{P}_{2} \mathrm{O}_{5} \quad \ldots$ & $\ldots$ & $\ldots$ & $\ldots$ & $\ldots$ & $\ldots$ & $2 \cdot 46$ & ", & $2 \cdot 37$ & , \\
\hline Chlorides & $\ldots$ & $\ldots$ & $\ldots$ & $\ldots$ & $\ldots$ & $6 \cdot 76$ & ", & $7 \cdot 80$ & , \\
\hline Acidity... & $\ldots$ & $\ldots$ & $\ldots$ & $\ldots$ & $\ldots$ & 3.05 & $"$ & $2 \cdot 95$ & , \\
\hline
\end{tabular}

PEAT BATHs.

The material for these baths is obtained from the moors in the neighbourhood of Harrogate and consists of peaty earth highly charged with organic acids and containing a small proportion of iron. It is mixed to the consistence of thick pulp and raised by steam to a temperature of from $98^{\circ}$ to $104^{\circ} \mathrm{F}$. The duration of the bath was 20 minutes: it was taken by Subject B. on three successive days. The main object was to ascertain its effect, if any, on metabolism. Its effect on the blood pressure and on the blood was found to be the same as that of plain water at the same temperature.

Effect on metabolism. - The effect on the urinary output was as follows. A marked diminution in the quantity of urine passed was noted and in the excretion of urea, the other constituents showing no distinctive change. (Vide Table XVIII.)

TABLE XVIII.-Subject $B$.

\begin{tabular}{|c|c|c|c|c|c|c|c|c|c|}
\hline & - & & & & & \multicolumn{2}{|c|}{$\begin{array}{l}\text { Average } \\
\text { excretion of } \\
\text { free days. }\end{array}$} & \multicolumn{2}{|c|}{$\begin{array}{c}\text { Average } \\
\text { excretion, three } \\
\text { peat baths. }\end{array}$} \\
\hline Quantity & $\ldots$ & $\ldots$ & $\ldots$ & $\ldots$ & $\ldots$ & \multirow{2}{*}{\multicolumn{2}{|c|}{$\begin{array}{c}1206 \text { c.c. } \\
33.51 \text { grammes. }\end{array}$}} & \multicolumn{2}{|c|}{957 c.c. } \\
\hline Urea $\ldots$ & ... & $\ldots$ & $\ldots$ & $\ldots$ & $\ldots$ & & & $30 \cdot 94$ & mmes. \\
\hline Sulphates & $\ldots$ & $\ldots$ & $\ldots$ & $\ldots$ & $\ldots$ & 2.09 & , & 196 & ,, \\
\hline Uric acid & $\ldots$ & $\ldots$ & $\ldots$ & $\ldots$ & $\ldots$ & 0.501 & , & 0.494 & ,, \\
\hline $\mathrm{P}_{2} \mathrm{O}_{5} \quad \ldots$ & $\ldots$ & $\ldots$ & $\ldots$ & $\cdots$ & $\ldots$ & $2 \cdot 19$ & ," & $1 \cdot 89$ & , \\
\hline Chlorides & $\ldots$ & $\ldots$ & $\ldots$ & $\ldots$ & $\ldots$ & $9 \cdot 42$ & , & 846 & , \\
\hline Acidity & $\ldots$ & $\ldots$ & $\ldots$ & $\ldots$ & $\ldots$ & $2 \cdot 82$ & , & $2 \cdot 27$ & , \\
\hline
\end{tabular}

Thermal SUlPhUR Bath.

The so-called thermal sulphur bath is the strongest form of natural sulphur bath administered at Harrogate and consists of the pure sulphur water, undiluted, raised to the required temperature by passing through a "therma" or heating apparatus of coiled tubing. It contains about 235 grains per gallon of total solids, consisting chiefly of chlorides and carbonates of sodium, calcium, and magnesium, the chloride of sodium being largely in excess and the carbonates forming relatively a very small proportion of the whole. Sulphur occurs in the bath in the form of sodium sulphydrate, amounting to about two grains per gallon, and as sulphuretted hydrogen gas, about two cubic inches per gallon. It is the staple bath at Harrogate and was investigated to determine whether any effect on metabolism could be detected as the result of a short series. It was taken by Subject $\mathrm{C}$ on four successive days at a temperature of $98^{\circ} \mathrm{F}$. for 20 minutes. No appreciable effect was observed on the urinary constituents beyond a marked increase in the quantity voided, though possibly a more prolonged trial might be found to have a more distinctive influence.

\section{SUMmaRY OF ReSULTS AND THERAPEUTIC INDICATIONS.}

The high-frequency current since its introduction has been used in the treatment of a great variety of affections, both local and general. Among the general affections may be mentioned gout, chronic rheumatism, obesity, diabetes, neurasthenia and hysteria, anæmia and chlorosis, phthisis pulmonalis, atonic dilatation of the stomach, and chronic colitis. Among the local affections, skin diseases-such as lupus, lupus erythematosus, psoriasis, chronic eczema, acne rosacea, rodent ulcer, chronic callous ulcer, pruritus ani and vulvæ-and local affections of the nerves-such as sciatica neuralgia, local neuritis--are frequently treated by this form of electricity. In the treatment of hæmorrhoids good results are obtained from its use.
The physiological action of the current in its general application tends to confirm its use in cases of nutritional disorders, such as chronic gout, chronic rheumatism, and obesity, by reason of the changes effected in blood pressure and the stimulus given to metabolism, as shown by the plus heat production, the plus excretion of urea, of uric acid, and of $\mathrm{CO}$ and the loss of weight. The rise produced in the hæmoglobin value of the corpuscle points to its use in the above cases when anæmia is a prominent symptom and also as a useful adjunct in cases of simple anæmia and chlorosis. The distinct contraction of unstriped muscle fibre excited by the effleuve indicates a trial of the method in cases of atony of the hollow viscera and may also account for the striking results sometimes observed in the shrinking and disappearance of hæmorrhoids after repeated applications. The evidence for its real value in cases of diabetes and phthisis does not appear to rest upon a sufficiently large number of cases to carry conviction as to its superiority over other modes of treatment. With regard to its action in local affections of the nerves and skin the foregoing results offer no evidence for or against. In our judgment, after considerable experience of the methods, the results obtained from the local application of the current are, on the whole, more favourable than those obtained from its general use.

Electric immersion baths are used largely to induce restora. tion of contractile power in cases of muscular weakness or atrophy resulting from nerve lesions or essential muscular dystrophy; and in cases of neurasthenia and the latent form of hysteria. They are also useful as a general tonic measure in cases presenting no definite disease but suffering from slackness and want of tone. It is also claimed that they exercise a favourable influence in cases of chronic gout, with or without local manifestations of the disease. The fibrillary muscular contraction excited by the current furnishes a basis for its use in the first class of cases. To this muscular contraction is probably due the inhibition of the fall in blood pressure that would otherwise result from the effect of the warm bath; and this may account to some extent for the tonic and invigorating effect experienced after the bath. The results obtained on metabolism are not sufficiently striking to justify the frequent employment of these baths in cases of chronic gout unless the slight increase in elimination of urea and uric acid which followed the constant current may be considered an indication in this direction.

The light and ozone bath.-The introduction of the factors of the inhalation of ozone and the passage of the high-frequency current differentiate this bath from the ordinary electric-light bath. The striking results obtained on the hæmoglobin value of the blood point to its use in cases requiring sweating baths, in which anæmia is present, and further tend to show that the daily breathing for a stated time of air highly charged with ozone may be a useful auxiliary measure in the treatment of intractable cases of chlorosis and secondary anæmia.

The Greville and Dowsing baths are both used for much the same class of cases and their application may be considered under the head of general to the whole body and local to various parts. Touching their general application for the cure of diseases other than those affecting the joints, much more is claimed for them than we think can be substantiated. 'Thus they have been advocated for the cure of phthisis, chronic bronchitis, asthma, chronic kidney disease, heart disease, anæmia, dyspepsia, obesity, chronic alcoholism, skin diseases, and others, in each of which good results are said to have been obtained by one or other system. In some of these, as for instance, chronic kidney disease, the indications are clear for their use. In others, though a few cases of each are recorded as having derived benefit, the evidence is not sufficiently strong to warrant the supersession by these baths of better known and longer tried methods. It is in the chronic general diseases of which the prominent manifestation is arthritis that they are of most service, such as gout, rheumatism, arthritis deformans, gonorrhœal rheumatism, and especially in local affections of the joints, fibrous tissues, or nerves, such as chronic arthritis (gouty, rheumatic, traumatic), sprains, lumbago, sciatica, neuritis, and neuralgia. In these conditions better results are obtained and are prob. ably to be accounted for by the profound alteration in nutrition which results from the marked variations in blood pressure produced and from the rapid changes that take place in the volume of the blood-alterations in nutrition which are in part evidenced by the considerable changes that occur in the excretion of urea and uric acid. Whether one system 
presents any real advantage over the other we are not prepared to say.

The Berthe and Viohy bath.-This is chiefly used in cases of chronic gout and rheumatism or in functional derangement of the alimentary tract. The initial lowering of blood pressure by the steam heat and its subsequent restoration after the full bath excite changes in the volume of the blood and changes in the relation of blood plasma to tissue fluid, effects which are aided by the vigorous massage administered and which result in the liberation of waste products from the tissues and their elimination from the body. The urinary constituents do not show as marked a change as has been previously found by us to result from a similar bath, the Aix douche, ${ }^{6}$ in which there is no preliminary steam bath, and the difference is probably to be accounted for, at least in the case of urea, by the fact that some of the urea is carried off in the perspiration excited in the Berthe box.

The peat baths. -These are largely used in cases of chronic pelvic disorder of an inflammatory nature. Their action, which resembles that of a wide-spread poultice, materially aids in the absorption of effused products. They are also used for cases of chronic intractable rheumatism and gout and in local manifestation of these disorders, such as lumbago or sciatica. The results obtained by us are not conclusive enough to indicate strongly in which direction they are likely to be of service.

The thermal sulphur bath. - These baths are largely used at Harrogate in the treatment of gout, rheumatism, and functional derangements of the liver and also for their local action on the skin in cases of skin disease. In the former as well as the latter, experience shows that they are of andoubted value, though their mode of action is by no means clear. Apart from their marked effect upon blood pressure, which has been previously shown, ${ }^{7}$ this investigation proved nothing conclusive as to their influence on metabolism.

In conclusion, we wish to record our appreciation of the courtesy shown to us by Mr. A. H. Marshall, the chairman, and the late Mr. A. H. Davis, the manager of the Royal Baths, in affording us facilities for the use of the baths during the investigation.

\section{A CASE OF EXTENSIVE CUTANEOUS DIPHTHERIA WITH AN EXAMINA- TION OF THE NERVOUS SYSTEM.}

By CHARLES BOLTON, M.D., B.Sc. LoND., M.R.C.P. LOND., FELLOW OF UNIVERSITY COLLEGE; ASSISTANT PHYSICIAN TO UNIVERSITY COLITGE HOSPITAL, AND TO THE NORTH-EASTERN HOSPITAL; AND

DUNSTAN BREWER, M.R.C.S. ENG., L.R.C.P. LOND., D.P.H.R.C.P.S. LoND.,

ASSISTANT MEDICAL OFFICER AT THE HOMERTON FEVER HOSPITAL

THAт diphtheria may attack a wound and lead to death by systemic poisoning is a familiar fact to every medical practitioner. The following case, however, presents several points of interest and from its extent and pathological characters vividly recalls to mind those cases of cutaneous diphtheria which were so common during the epidemics of the early part of the nineteenth century and concerning which the physicians of that period wrote but which are now comparatively rare and almost forgotten. We have, therefore, by the courtesy of Dr. E. W. Goodall, taken the opportunity of placing it on record.

Before Bretonneau's time Chomel ${ }^{1}$ in 1759 , Starr $^{2}$ in England and Samuel Bard ${ }^{3}$ in America in 1771 had drawn attention to a membranous affection of the skin. Bretonneau in his first memoir gives examples of this affection and demonstrates that diphtheria in whatever locality it occurs

6 Bain and Edgecombe: Journal of Physiology, vol. xxiii., 1899.

7 Edgecombe and Bain : Effect of Baths, Massage, and Bxercise on Blood Pressure, The LanceT, June 10th, 1899 , p. 1552

1 Quoted by Trousseau, Clinique Médicale, tenth edition, book i. p. 472 .

1859, p. 18

3 Ibid. in the body has everywhere the same characters. In 1828 , during the epidemics at Sologne, Trousseau and Ramon collected many cases which are described with great care. According to Trousseau diphtheria never develops on the skin unless the latter is previously deprived of its epidermis or ulcerated and the lesions which he has found to be affected with diphtheria are blisters, leech-bites, cuts, herpes, cracks of the breast, excoriations of the genital organs, of the ears, of the hairy scalp, of the nose, of the anus, and different wounds. He describes a case in which the vulva and the skin of the folds of the thighs were affected and which appears to have been very similar to our own. The commonest starting-point appears to bave been in a blister applied to the neck.

With regard to the pathological appearances of a wound affected with diphtheria Trousseau says that it first becomes painful, a "colourless foetid serosity" escapes, and a thick greyish flabby membrane appears on the surface. The edges of the wound are swollen and violet-red in colour. The disease does not usually extend but remains stationary for months. When the epidermis alone is removed the raw surface becomes covered with a white membrane and a kind of "erysipelas" soon develops round it. On the surface of the latter the epidermis is elevated in many points by small masses of "lactescent serosity." The vesicles thus formed run together and burst, the exposed dermis being then covered with a white membrane. These new centres join to the main centre and to each other and so the disease spreads. The pellicular concretions gradually become thicker and the most exterior layers become softened, putrid, greyish-black, and fotid. In one case he saw gangrene attack the part. The invasion generally takes place from the superposed parts towards the dependent parts, this probably being due to the irritation of the serous secretion. He has seen it commence on the hairy scalp and spread to the loins. When the disease extends rapidly the fever may be very acute but it is usually like the hectic fever accompanying suppuration. The patients died after the manner of those suffering from malignant diphtheria. Daviot ${ }^{5}$ states that he had most commonly seen cutaneous diphtheria occur spontaneously, although Trousseau maintains that it is alwass preceded by a breach of surface.

The preceding remarks are quite sufficient without any further references to the literature to show that outaneous diphtheria was a frequent and fatal affection during the epidemics of that period and that it was liable to be very extensive.

In the case under consideration the patient was sent to the Homerton Fever Hospital on Sept. 30th, 1903, by Mr. A. F. Cole certified to be suffering from diphtheria. $\mathrm{Mr}$. Cole gave the following history of the case: "The patient a female child, aged one and a half years, was brought to the out-patient department of the Mildmay Mission Hospital, Bethnal Green, E., on Sept. 29th, 1903. The mother stated that there was a 'sore' in the left groin which had been increasing gradually for seven days: that it had come 'by itself,' and even on careful inquiry no history of any scratch or wound of any kind could be obtained; her brothers and sisters were quite well. On examination there was a gangrenous patch with sinuous edges and about three by two inches in extent surrounded by an inflammatory areola about half an inch in width. It commenced in the groin where the site of ulceration was occupied by a blackish scab and was apparently spreading upwards mainly on the abdominal wall. This more recent ulceration showed what were evidently sloughing portions of skin of a dirty white colour. There was nothing to be seen approaching the appearance of a membrane and the edges gradually merged into healthy skin, but in the more central portion the loss of substance was considerable. The left labium majus was greatly swollen but no trace of ulceration could be found upon it. No glandular enlargement was observed. The child did not seem to be very ill at this time dressings saturated with 1 in 4000 biniodide of mercury were applied and she was taken home. On seeing the child again that evening she was admitted to the children's ward. Within one hour of her admission smears and cultures from the surface of the gangrenous patch were taken. The smears revealed typical bacillus diphtheriæ and the same organism was grown in pure culture upon the serum."

4 Dictionnaire de Médecine, 1835; Archives Générales de Médecine 1830 , tome xxi., p. 541 , and tome xxiii., p. 383 .

5 Relation d'une Épidémie de Diphtheropathie, Gazette Médicale, 1846, p. 178. 